\title{
Antidiabetic, antioxidant and anti-inflammatory activity of medicinal plants collected from nearby area of Junagadh, Gujarat
}

\author{
Punit R. Bhatt, Kajal B. Pandya, Urvesh D. Patel`, Chirag M. Modi, Harshad B. Patel and Bhavesh B. Javia \\ College of Veterinary Science and A.H., Junagadh Agricultural University, Junagadh-362 001, Gujarat, India
}

Received October 11, 2019: Revised December 11, 2019: Accepted December 15, 2019: Published online December 30,2019

\begin{abstract}
The present study was planned to carry out phytochemical analysis and to evaluate in vitro antidiabetic, antioxidant and anti-inflammatory activities of different extracts of six medicinal plants collected from the nearby area of Junagadh, Gujarat, India, viz., Luffa echinata Roxb. (fruit), Operculina turpethum (L.) Silva Manso (leaf), Sphaeranthus indicus L. (fruit), Cressa cretica L. (leaf), Corchorus depressus L. (root) and Cassia absus (seed). An in vitro antidiabetic activity was evaluated by alpha-amylase and alpha-glucosidase inhibition methods, antioxidant activity by DPPH (2, 2-diphenyl-1 - picrylhydrazyl) assay and anti-inflammatory activity by albumin denaturation assay. Hydro-alcoholic and methanolic extracts of L.echinata, water extract of C.cretica and methanolic and hydro-alcoholic extracts of $C$. depressus showed significant inhibition either of alpha-amylase or alpha-glucosidase or both in vitro at various concentrations. Hydro-alcoholic and methanolic extracts of L. echinata fruit and hydroalcoholic and methanolic extracts of $S$. indicus fruit showed significant in vitro antioxidant effect. Water extract of $O$. turpethum leaf showed significant anti-inflammatory activity by preventing albumin denaturation in vitro. Phytochemical analysis revealed the presence of glycosides, flavonoids, alkaloids, tannins and steroids in different extracts of medicinal plants which might be responsible for significant in vitro antidiabetic, antioxidant and antiinflammatory activities. Identification and isolation of active substances from such plants and in vivo efficacy evaluation will be helpful for further validation of pharmacological activities of these medicinal plants.
\end{abstract}

Key words: Medicinal plants, antidiabetic, antioxidant, anti-inflammatory, in vitro assays

\section{Introduction}

According to the WHO, $88 \%$ population of about 198 countries in the world use traditional medicines. Many countries have formulated a policy on conventional medicine (WHO, 2019). Saurashtra region of Gujarat is a large biodiversity region with several medicinal plants. Since a long time, these medicinal plants are used in the ethnoveterinary practices as well as in the ailments of human or animals (Bhatt et al., 2019a). The main advantages of medicinal plants are, they are economical, readily available and has no side effects. Many medicinal plants from Saurashtra region are reported to have antidiabetic, antibacterial, anti-inflammatory and antioxidant effects (Kaneria et al., 2009; Modi et al., 2019; Patel et al., 2019).

Medicinal plants are having an antidiabetic action exerted with different mechanisms like inhibition of blood glucose level by maintaining various enzymes like alpha-amylase and alpha-glucosidase

\footnotetext{
Author for correspondence: Dr. Urvesh D. Patel

Associate Professor, Department of Veterinary Pharmacology and Toxicology, College of Veterinary Science and A.H., Junagadh Agricultural University, Junagadh 362 001, India

E-mail: urvesh1981@yahoo.com

Tel.: +91-9725003818
}

(Modak et al., 2007). Many degenerative diseases such as coronary heart disease, inflammation, stroke, diabetes mellitus and cancer occur due to the high level of free radicals in the body. Diabetes is a major degenerative disorder which is listed as an incurable disease as per World Health Organisation (WHO, 2018). Phytochemicals like flavonoids, phenolic compounds, phenolic acids, etc., are known to have strong antioxidant action. These kinds of phytochemicals are found in many medicinal plants (Bhatt et al., 2019b). Antioxidant activity of plants is attributed via simple redox reactions which occur in various biochemical processes by saturating lone-pair from free radicals, also called reactive oxygen species (ROS) (Brown and Rice-Evans, 1998; Scalbert et al., 2005). Inflammation is a response which occurs due to damage to the body by physical or chemical agents. It is characterised by pain, redness, swelling, heat and lack of function (Tortora and Sandra, 1993). Many synthetic drugs like indomethacin, aspirin, ibuprofen, diclofenac and aceclofenac have potent anti-inflammatory action, but due to significant side effects like kidney failure, damage to the liver and upper GIT bleeding, many drugs are either banned or less used for long term treatment (Patidar et al., 2014). Medicinal plants are a rich source of a variety of phytochemicals like saponin, triterpenoid, flavonoids, alkaloids, which possess anti-inflammatory action via different mechanisms like inhibition COX enzymes, albumin denaturation and protease inhibition (Fawole et al., 2010; Modi et al., 2019). 
Six medicinal plants (Luffa echinata Roxb., Operculina turpethum (L.) Silva Manso, Sphaeranthus indicus L., Cressa cretica L., Corchorus depressus L., and Cassia absus L.) were selected in the present study. Traditionally, Luffa echinata is used in jaundice, Operculina turpethum as purgative, Sphaeranthus indicus in hepatic and gastric disorders as well as a blood purifier, Cressa cretica as an expectorant, Corchorus depressus in wound healing and Cassia absus as blood-purifier and used in various skin disorders (Khare, 2007). Limited or no studies have been reported for antidiabetic, antioxidant and anti-inflammatory activity of aqueous, hydro-alcoholic and methanolic extracts of above mentioned plants. Therefore, the plants have been selected for the evaluation of the antidiabetic, antioxidant and anti-inflammatory activity through in vitro assays.

\section{Materials and Methods}

\subsection{Collection and processing of plant material}

All the plant materials were collected from the surroundings of Junagadh, Gujarat, India and identified and authenticated by Pharmacognosist (Table 1). A specimen of each plant material was deposited in the Department of Veterinary Pharmacology and Toxicology, Veterinary College, JAU, Junagadh. Specimen voucher numbers are mentioned in Table 1. Collected plant materials were washed with tap water and dried in an oven at $45^{\circ} \mathrm{C}$. The material was grounded, and the fine powder was stored in an air-tight container until use.

Table 1: List of medicinal plants used for the study

\begin{tabular}{|c|l|l|l|l|}
\hline $\begin{array}{c}\text { Sr. } \\
\text { No. }\end{array}$ & Name of plantwith herbarium number & Family & $\begin{array}{l}\text { Vernacular name } \\
\text { (Gujarati) }\end{array}$ & \multicolumn{1}{|c|}{ Part of plant used } \\
\hline 1 & Luffa echinata Roxb. (JVC/VPT/SP/PS/01/2016) & Cucurbitaceae & Kukadvel \\
2 & Operculina turpethum L. Silva Manso (JVC/VPT/SP/PS/02/2016) & Convolvulaceae & Nasotar \\
3 & Sphaeranthus indicus L. (JVC/VPT/SP/PS/03/2016) & Compositae & Gorakhmundi \\
4 & Cressa cretica L. (JVC/VPT/SP/PS/04/2016) & Convolvulaceae & Rudanti \\
5 & Corchorus depressus L. (JVC/VPT/SP/PS/05/2016) & Tiliaceace & Bahufali & Leaf \\
6 & Cassia absus L. (JVC/VPT/SP/PS/06/2016) & Caesalpiniaceae & Chimed \\
\hline
\end{tabular}

\subsection{Preparation of extracts}

All powders were used to prepare different solvent extracts (water, methanol and hydro-alcoholic) by maceration. The hydro-alcoholic extract from each powder was prepared using methanol and water with the ratio of 80:20. The extracts were obtained by dissolving 25 grams of the powder in $250 \mathrm{ml}$ of each solvent for $24 \mathrm{~h}$, then contents were filtered through Whatman filter paper no.1, and the filtrate was evaporated for dryness (Sarker et al., 2006). The test extracts in sufficient quantities were prepared and stored at $-20^{\circ} \mathrm{C}$ for further use. The per cent extractability (yield) of plants was calculated by the formula: [Total amount of dried extract x 100 / Total amount of raw powder taken]. The physical characteristics of all extracts were also recorded.

\subsection{Phytochemical screening and total phenolic content}

Qualitative phytochemical screening was performed for each extract as per standard procedures (Harborne, 1998). All the chemicals of analytical grades were used for qualitative analysis of different phytochemical constituents in different extracts of plants as per standard methods (Iqbal et al., 2015). For total phenolic content assay, 2501 of extract solution was allowed to react with $2 \mathrm{ml}$ Folin-Ciocalteu (FC) reagent (previously diluted 1:10) and $1 \mathrm{ml}$ solution $(75 \mathrm{~g} / \mathrm{l})$ of sodium carbonate. The mixture was allowed to stand for 1 to $2 \mathrm{~h}$. Extinction was recorded at $760 \mathrm{~nm}$ in a spectrophotometer. Tests were performed in triplicate. Total phenolic content (TPC) was expressed as milligrams of gallic acid equivalents (GAE) (Encarnacao et al., 2015).

\subsection{In vitro antidiabetic activity}

\subsubsection{Alpha-amylase inhibition assay}

Alpha-amylase inhibition was evaluatedby Dinitro Salicylic acid (DNS) method, $500 \mu \mathrm{l}$ extracts $(10,25,50,75,100,200 \mu \mathrm{g} / \mathrm{ml})$ or standard solution (Acarbose $1 \mathrm{mg} / \mathrm{ml}$ in distilled water) were prepared in buffer solution. The mixture was added with $500 \mu \mathrm{l} \alpha$-amylase (from malt) solution and $1 \mathrm{ml}$ starch solution. The mixture was mixed properly and put the reaction mixture in an incubator for 5 to $10 \mathrm{~min}$. DNS reagent $(1 \mathrm{ml})$ was added into the reaction mixture, and immediately test-tubes were put in boiled water for $3 \mathrm{~min}$. The test tubes with mixture were cooled at room temperature and added with $6 \mathrm{ml}$ distilled water. The extinction of mixture was read at $540 \mathrm{~nm}$ in UV spectrophotometer. The control solution was prepared by adding all reagents except test or standard (Wan et al., 2013).

\subsubsection{Alpha-glucosidase inhibition assay}

One hundred and twenty micro litters of different extract $(200,400,600,800,1000 \mu \mathrm{g} / \mathrm{ml}$ ) or standard solution (Acarbose $1 \mathrm{mg}$ / $\mathrm{ml}$ in distilled water) were prepared in buffer solutions, were taken in 96-well plate having a transparent and flat bottom. Twenty micro litres of $\alpha$-glucosidase (from Saccharomyces cerevisiae) solution $(1 \mathrm{U} / \mathrm{ml})$ was added and incubated for $15 \mathrm{~min}$. After incubation, to initiate the reaction, $20 \mu 1 \mathrm{p}$-Nitrophenyl $\alpha$-D-Glucoside (pNPG) solution was added and again incubated for $15 \mathrm{~min}$ till the development of yellow colour in the reaction mixture. To terminate the reaction, $80 \mu 10.1 \mathrm{M} \mathrm{Na}_{2} \mathrm{CO}_{3}$ solutions were added, and extinction of the reaction mixture was read at $405 \mathrm{~nm}$ in the UV spectrophotometer (Zhipeng et al., 2012).

\subsection{In vitro antioxidant activity}

\subsubsection{DPPH (2, 2-diphenyl-1-picrylhydrazyl) scavenging activity}

Extract solution $(1 \mathrm{mg} / \mathrm{ml})$ was prepared by dissolving $30 \mathrm{mg}$ of aqueous extract in $30 \mathrm{ml}$ Milli-Q water. The hydro-alcoholic extract was dissolved by incorporating $10 \%$ DMSO as a solvent. Suitable dilutions were made from this stock solution with Milli-Q water only. Three ml extracts $(10,25,50,75,100,200 \mu \mathrm{g} / \mathrm{ml})$ or standard 
solution (Ascorbic acid $1 \mathrm{mg} / \mathrm{ml}$ ) were prepared in distilled water. One $\mathrm{ml}$ of $0.1 \mathrm{mM}$ DPPH solution (4 mg in $100 \mathrm{ml}$ methanol) was added. The solution was kept for $30 \mathrm{~min}$ at room temperature until the colour changed from violet to yellowish violet to yellow. Extinction at $517 \mathrm{~nm}$ in spectrophotometer was recorded. A blank solution containing distilled water and DPPH alone (Control) were also prepared, and spectra were recorded for control purpose. Tests were performed in triplicate (Senguttuvan et al., 2014).

\subsection{In vitro anti-inflammatory activity}

\subsubsection{Albumin denaturation inhibition assay}

One millilitre of test extract $(100,200,300,400,500 \mu \mathrm{g} / \mathrm{ml})$ or standard solution (Aspirin $1 \mathrm{mg} / \mathrm{ml}$ ) were prepared in buffer. $1 \mathrm{ml}$ $(0.1 \%)$ of bovine albumin fraction and $1 \mathrm{ml}$ Tris- $\mathrm{HCl}$ buffer $\mathrm{pH} 7.8$ solution were added. This solution was incubated for $20 \mathrm{~min}$ and allowed to heat at $72^{\circ} \mathrm{C}$ in a water bath for $4 \mathrm{~min}$, then cooled at room temperature. Extinction was measured at $660 \mathrm{~nm}$ using a blank solution (Buffer). Control solution contained $1 \mathrm{ml}$ distilled water with $1 \mathrm{ml}(0.1 \%)$ bovine albumin fraction and $1 \mathrm{ml}$ buffer solution (Williams et al., 2008; Alhakmani et al., 2014).

\subsection{Statistical analysis}

All numerical data are expressedas mean \pm Standard Error (SE). Selected data have been analyzed by one-way ANOVA, followed by the Duncan Multiple Range Test (DMRT) to compare the differences in means.

\section{Results}

\subsection{Physical characteristics and phytochemical screening}

Per cent yield and appearance of each extract presented in Table 2. It was found that, in most cases, water extract gave more per cent yield as compared to other extracts. However, hydro-alcoholic extracts also gave good yield due to the incorporation of water in the preparation of extracts. Qualitative phytochemical screening was performed for each extract which is mentioned in Table 3.

Table 2: Per cent yield and appearance of the different extracts of medicinal plants

\begin{tabular}{|c|c|c|c|c|c|}
\hline Sr. No. & Name of plant & Extract & Code & Appearance & Yield (\%) \\
\hline 1 & Luffa echinata & $\begin{array}{l}\text { HAE } \\
\text { ME } \\
\text { WE }\end{array}$ & $\begin{array}{l}\text { LEHA } \\
\text { LEM } \\
\text { LEW }\end{array}$ & $\begin{array}{l}\text { Yellowish-brown } \\
\text { Dark green } \\
\text { Dark brown }\end{array}$ & $\begin{array}{l}9.45 \\
8.89 \\
7.03\end{array}$ \\
\hline 2 & Operculinaturpethum & $\begin{array}{l}\text { HAE } \\
\text { ME } \\
\text { WE }\end{array}$ & $\begin{array}{l}\text { OTHA } \\
\text { OTM } \\
\text { OTW }\end{array}$ & $\begin{array}{l}\text { Dark brown mass } \\
\text { Dark Green mass } \\
\text { Brownish-yellow solid }\end{array}$ & $\begin{array}{l}4.70 \\
3.65 \\
11.9\end{array}$ \\
\hline 3 & Sphaeranthus indicus & $\begin{array}{l}\text { HAE } \\
\text { ME } \\
\text { WE }\end{array}$ & $\begin{array}{l}\text { SIHA } \\
\text { SIM } \\
\text { SIW }\end{array}$ & $\begin{array}{l}\text { Dark brown mass } \\
\text { Yellowish-brown mass } \\
\text { Yellowish-brown }\end{array}$ & $\begin{array}{l}7.04 \\
7.82 \\
8.64\end{array}$ \\
\hline 4 & Cressacretica & $\begin{array}{l}\text { HAE } \\
\text { ME } \\
\text { WE }\end{array}$ & $\begin{array}{l}\mathrm{CCHA} \\
\mathrm{CCM} \\
\mathrm{CCW}\end{array}$ & $\begin{array}{l}\text { Yellowish-brown } \\
\text { Dark green } \\
\text { Dark brown }\end{array}$ & $\begin{array}{l}16.86 \\
14.85 \\
16.24\end{array}$ \\
\hline 5 & Corchorusdepressus & $\begin{array}{l}\text { HAE } \\
\text { ME } \\
\text { WE }\end{array}$ & $\begin{array}{l}\text { CDHA } \\
\text { CDM } \\
\text { CDW }\end{array}$ & $\begin{array}{l}\text { Dark brown mass } \\
\text { Dark yellow mass } \\
\text { Black solid }\end{array}$ & $\begin{array}{l}7.60 \\
5.00 \\
4.70\end{array}$ \\
\hline 6 & Cassia absus & $\begin{array}{l}\text { HAE } \\
\text { ME } \\
\text { WE }\end{array}$ & $\begin{array}{l}\text { CAHA } \\
\text { CAM } \\
\text { CAW }\end{array}$ & $\begin{array}{l}\text { Dark brown } \\
\text { Yellowish-brown } \\
\text { Dark brown }\end{array}$ & $\begin{array}{r}13.18 \\
1.72 \\
14.56\end{array}$ \\
\hline
\end{tabular}

HAE: Hydro-alcoholic extract, ME: Methanol extract; WE: Water extract; Extract codes are used in figures

\subsection{In vitro antidiabetic activity}

The data of per cent inhibition of alpha-amylase by various extracts of plants and acarbose are depicted in Figure 1. The methanol extract of $C$. depressus produced significantly $(p<0.05)$ higher inhibition up to $61.97 \pm 0.81$ per cent of alpha-amylase at $500 \mu \mathrm{g} / \mathrm{ml}$ concentration as compared to per cent inhibition of acarbose $52.69 \pm$ 2.16 per cent. Water extract of C. cretica and hydro-alcoholic extract of $C$. absus showed inhibition up to $56.65 \pm 0.70$ and $56.52 \pm 0.92$ per cent, respectively at $500 \mu \mathrm{g} / \mathrm{ml}$ concentration. However, the inhibition by both these extracts was found comparable to inhibition by acarbose which indicates well antidiabetic activity of these plant extracts via inhibition of alpha-amylase. The per cent inhibition of alpha-amylase by L. echinata methanol, O. turpethum methanol, C. cretica water, C. depressus water and C. absus hydro-alcoholic extracts at lower concentrations were also comparable to that of acarbose.
The data of per cent inhibition of alpha-glucosidase by various extracts of plants and acarbose are depicted in Figures 2 and 3. In case of alpha-glucosidase inhibition assay, hydro-alcoholic extract of L. echinata fruit and water extract of C. cretica leaf showed inhibition up to $78.70 \pm 0.25$ and $80.60 \pm 0.35$ per cent which were significantly $(p<0.05)$ higher than per cent inhibition of acarbose (76.91 \pm 0.47 per cent) at $1000 \mu \mathrm{g} / \mathrm{ml}$.

\subsection{In vitro antioxidant activity}

The data of per cent inhibition of DPPH (2, 2-diphenyl-1picrylhydrazyl) by various extracts of plants and ascorbic acid are depicted in Figures 4 and 5. The hydro-alcoholic extract of L. echinata, methanolic extract of $S$. indicus, hydro-alcoholic extract of $C$. cretica exhibited the significantly higher antioxidant activity than per cent inhibition of ascorbic acid (77.08 \pm 0.31 per cent). 
Table 3: Phytochemical screening of different extracts of medicinal plants

\begin{tabular}{|c|c|c|c|c|c|c|c|c|c|}
\hline Sr. No. & Name of plant & Type & ALK & GLY & SP & FLV & STR & СНО & TN \\
\hline 1 & Luffa echinata & $\begin{array}{l}\text { HAE } \\
\text { ME } \\
\text { WE }\end{array}$ & $\begin{array}{l}- \\
-\end{array}$ & $\begin{array}{l}+ \\
- \\
+\end{array}$ & $\begin{array}{l}- \\
- \\
-\end{array}$ & $\begin{array}{l}+ \\
+ \\
+\end{array}$ & $\begin{array}{l}+ \\
+ \\
-\end{array}$ & $\begin{array}{l}- \\
+ \\
+\end{array}$ & $\begin{array}{l}+ \\
+ \\
+\end{array}$ \\
\hline 2 & Operculina turpethum & $\begin{array}{l}\text { HAE } \\
\text { ME } \\
\text { WE }\end{array}$ & $\begin{array}{l}- \\
-\end{array}$ & $\begin{array}{l}+ \\
+ \\
+\end{array}$ & $\begin{array}{l}- \\
- \\
+\end{array}$ & $\begin{array}{l}- \\
+ \\
+\end{array}$ & $\begin{array}{l}- \\
- \\
-\end{array}$ & $\begin{array}{l}+ \\
- \\
+\end{array}$ & $\begin{array}{l}+ \\
- \\
+\end{array}$ \\
\hline 3 & Sphaeranthus indicus & $\begin{array}{l}\text { HAE } \\
\text { ME } \\
\text { WE }\end{array}$ & $\begin{array}{l}+ \\
+ \\
+\end{array}$ & $\begin{array}{l}+ \\
- \\
+\end{array}$ & $\begin{array}{l}+ \\
- \\
+\end{array}$ & $\begin{array}{l}+ \\
+ \\
+\end{array}$ & $\begin{array}{l}- \\
+ \\
-\end{array}$ & $\begin{array}{l}+ \\
+ \\
+\end{array}$ & $\begin{array}{l}- \\
- \\
+\end{array}$ \\
\hline 4 & Cressa cretica & $\begin{array}{l}\text { HAE } \\
\text { ME } \\
\text { WE }\end{array}$ & $\begin{array}{l}- \\
-\end{array}$ & $\begin{array}{l}+ \\
+ \\
+\end{array}$ & $\begin{array}{l}+ \\
- \\
-\end{array}$ & $\begin{array}{l}+ \\
+ \\
+\end{array}$ & $\begin{array}{l}- \\
+ \\
-\end{array}$ & $\begin{array}{l}+ \\
+ \\
+\end{array}$ & $\begin{array}{l}+ \\
- \\
+\end{array}$ \\
\hline 5 & Corchorus depressus & $\begin{array}{l}\text { HAE } \\
\text { ME } \\
\text { WE }\end{array}$ & $\begin{array}{l}- \\
-\end{array}$ & $\begin{array}{l}- \\
+\end{array}$ & $\begin{array}{l}+ \\
- \\
+\end{array}$ & $\begin{array}{l}+ \\
+ \\
+\end{array}$ & $\begin{array}{l}+ \\
+ \\
-\end{array}$ & $\begin{array}{l}+ \\
- \\
+\end{array}$ & $\begin{array}{l}+ \\
- \\
+\end{array}$ \\
\hline 6 & Cassia absus & $\begin{array}{l}\text { HAE } \\
\text { ME } \\
\text { WE }\end{array}$ & $\begin{array}{l}+ \\
+ \\
+\end{array}$ & $\begin{array}{l}+ \\
- \\
+\end{array}$ & $\begin{array}{l}+ \\
- \\
+\end{array}$ & $\begin{array}{l}+ \\
+ \\
+\end{array}$ & $\begin{array}{l}- \\
+ \\
-\end{array}$ & $\begin{array}{l}+ \\
+ \\
+\end{array}$ & $\begin{array}{l}- \\
- \\
+\end{array}$ \\
\hline
\end{tabular}

ALK: Alkaloid, GLY: Glycoside, SP: Saponin, FLV: Flavonoid, STR: Steroid, CHO= carbohydrate/sugars TN: Tannin, HAE: Hydro-alcoholic extract; ME: Methanol extract; WE: Water extract; '+'=present; '-'=absent.

\subsection{In vitro anti-inflammatory activity}

The data of per cent inhibition of albumin denaturation by various extracts of plants and aspirin are depicted in Figure 6. Results showed that all the selected extracts showed more or less inhibition of albumin denaturation compared to aspirin at various concentrations. Aqueous extract of $O$. turpethum $(500 \mu \mathrm{g} / \mathrm{ml})$ showed significant $(p<0.05)$ albumin denaturation inhibitory activity of $84.10 \pm 0.34 \%$ which was comparable to that of aspirin $(90.17 \pm 1.28$ per cent). All other selected extracts exhibited inhibition between 40 to $70 \%$.

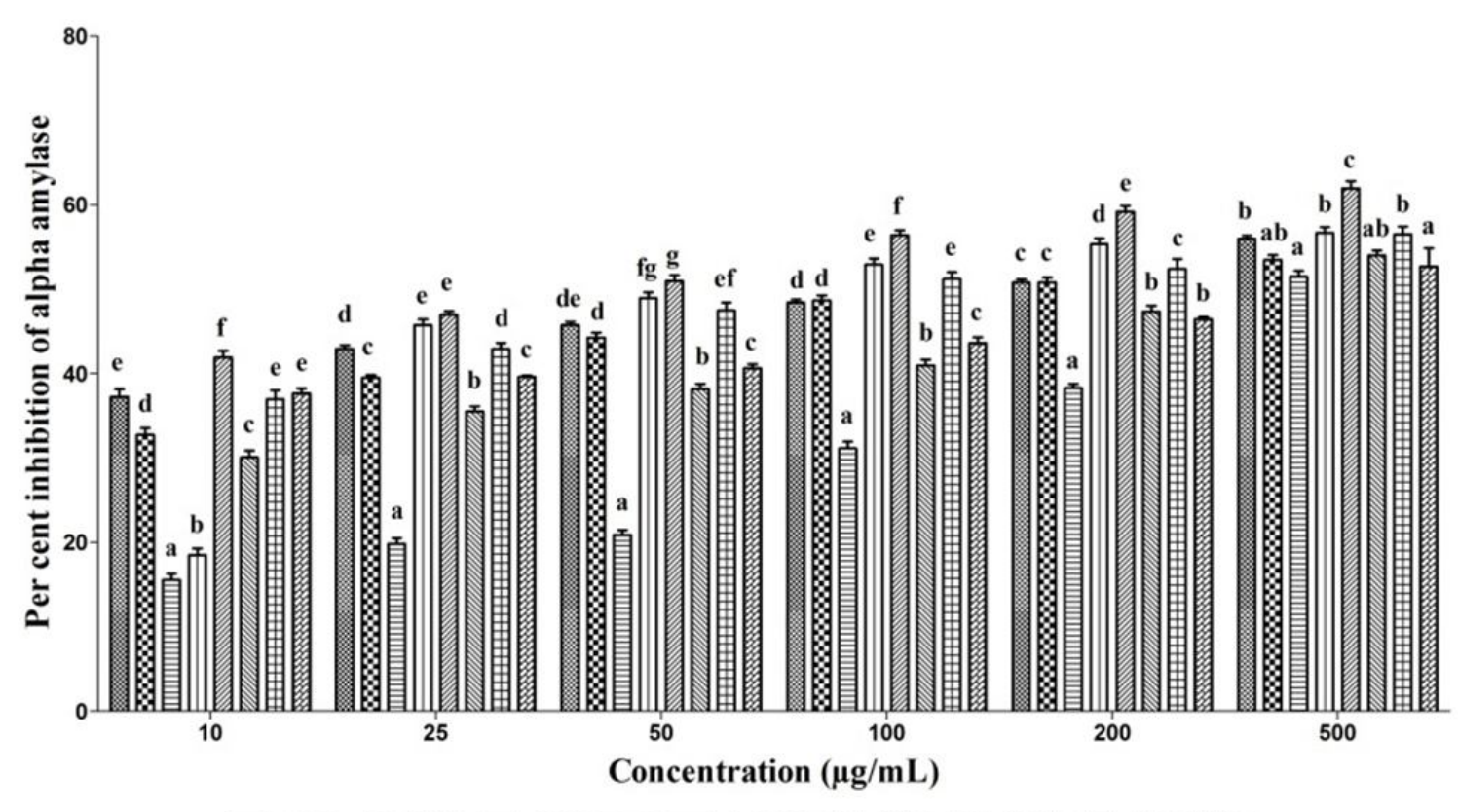

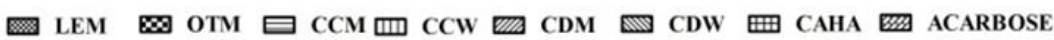

Figure 1: Per cent inhibition of alpha-amylase by various extracts of plants and acarbose. Values with different superscript were differ significantly at respective concentration $(p<0.05)$. 


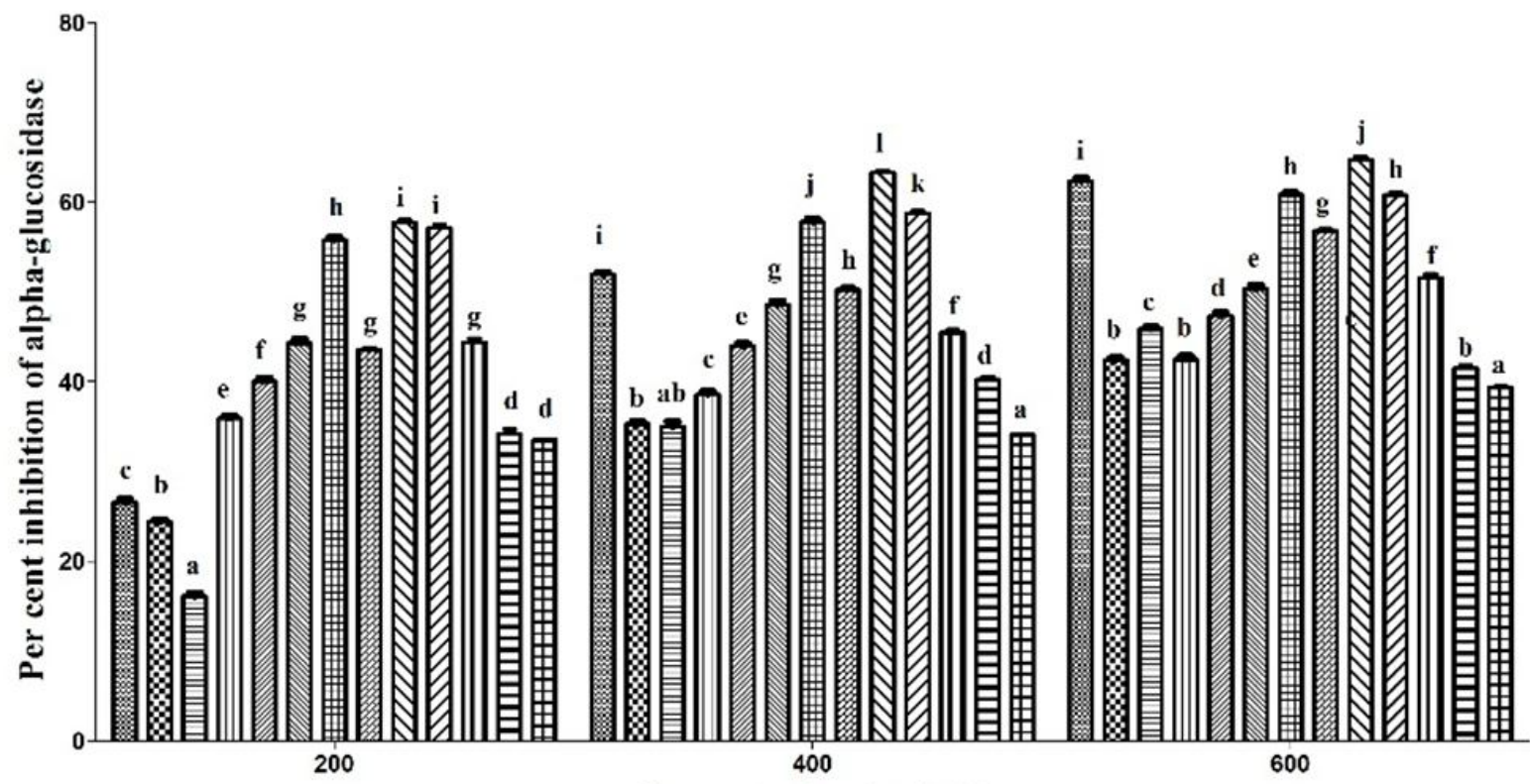

Concentration $(\mu \mathrm{g} / \mathrm{mL})$

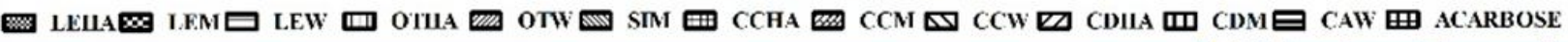

Figure 2: Per cent inhibition of alpha-glucosidase by various extracts of plants and acarbose.Values with different superscript were differ significantly at respective concentration $(p<0.05)$.

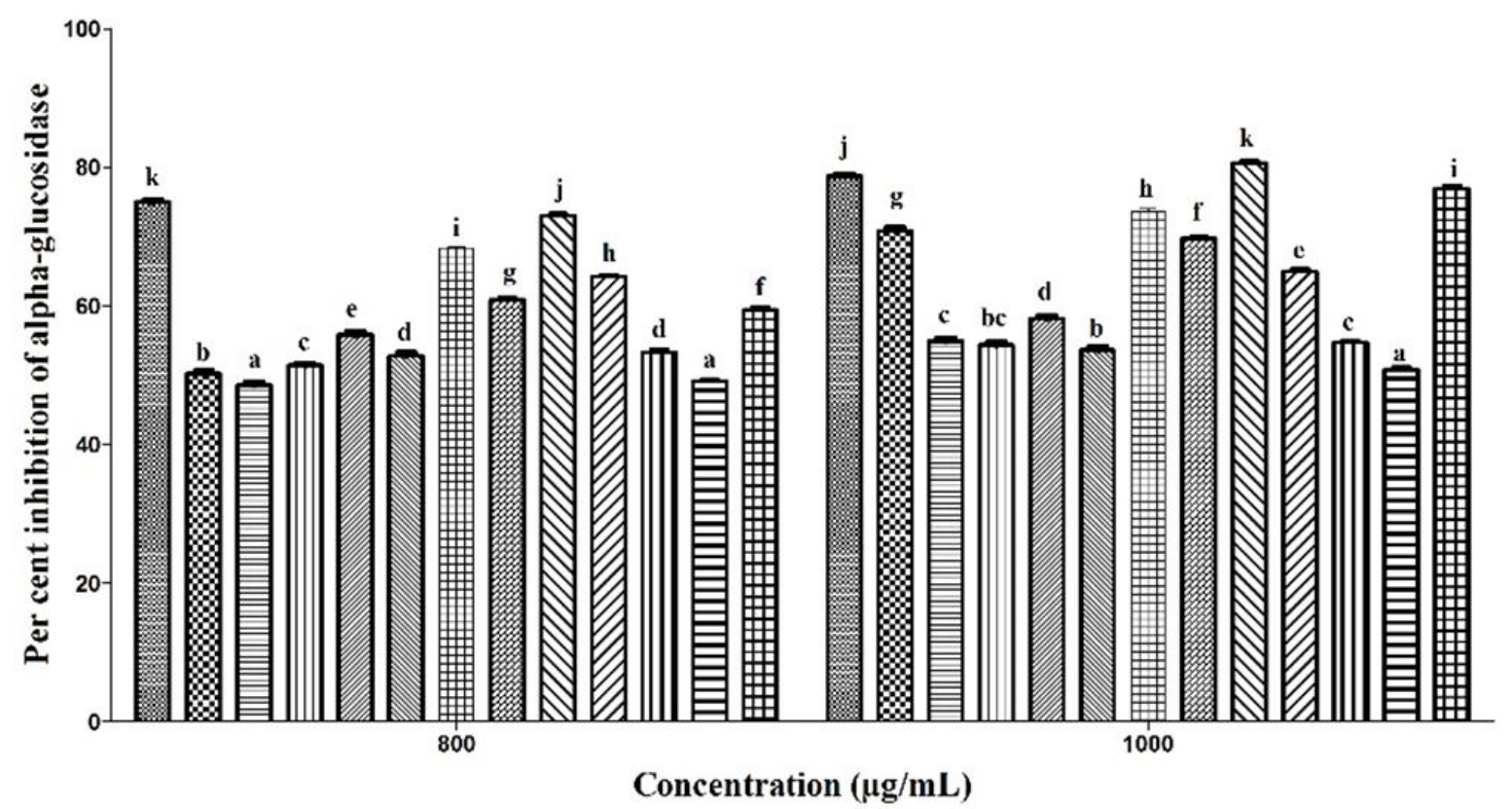

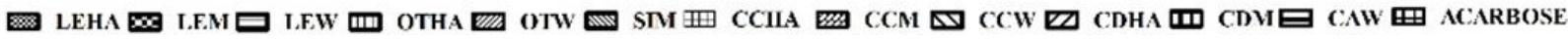

Figure 3: Per cent inhibition of alpha-glucosidase by various extracts of plants and acarbose. Values with different superscript were differ significantly at respective concentration $(p<0.05)$. 


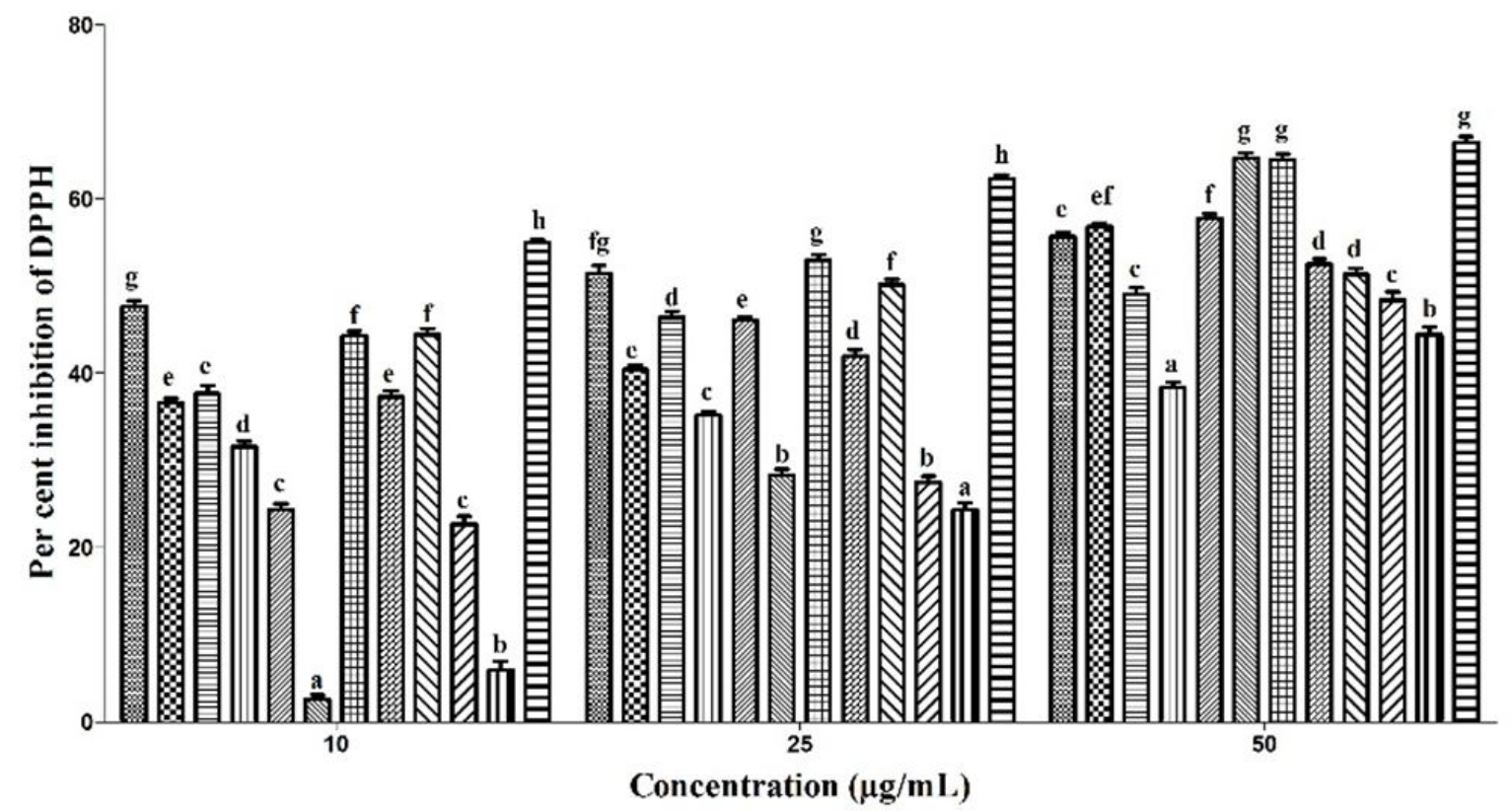

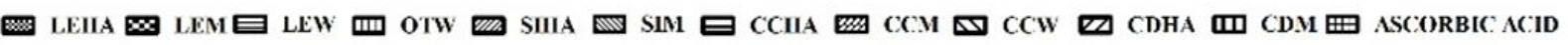

Figure 4: Per cent inhibition of DPPH by various extracts of plants and ascorbic acid. Values with different superscript were differ significantly at respective concentration $(p<0.05)$.

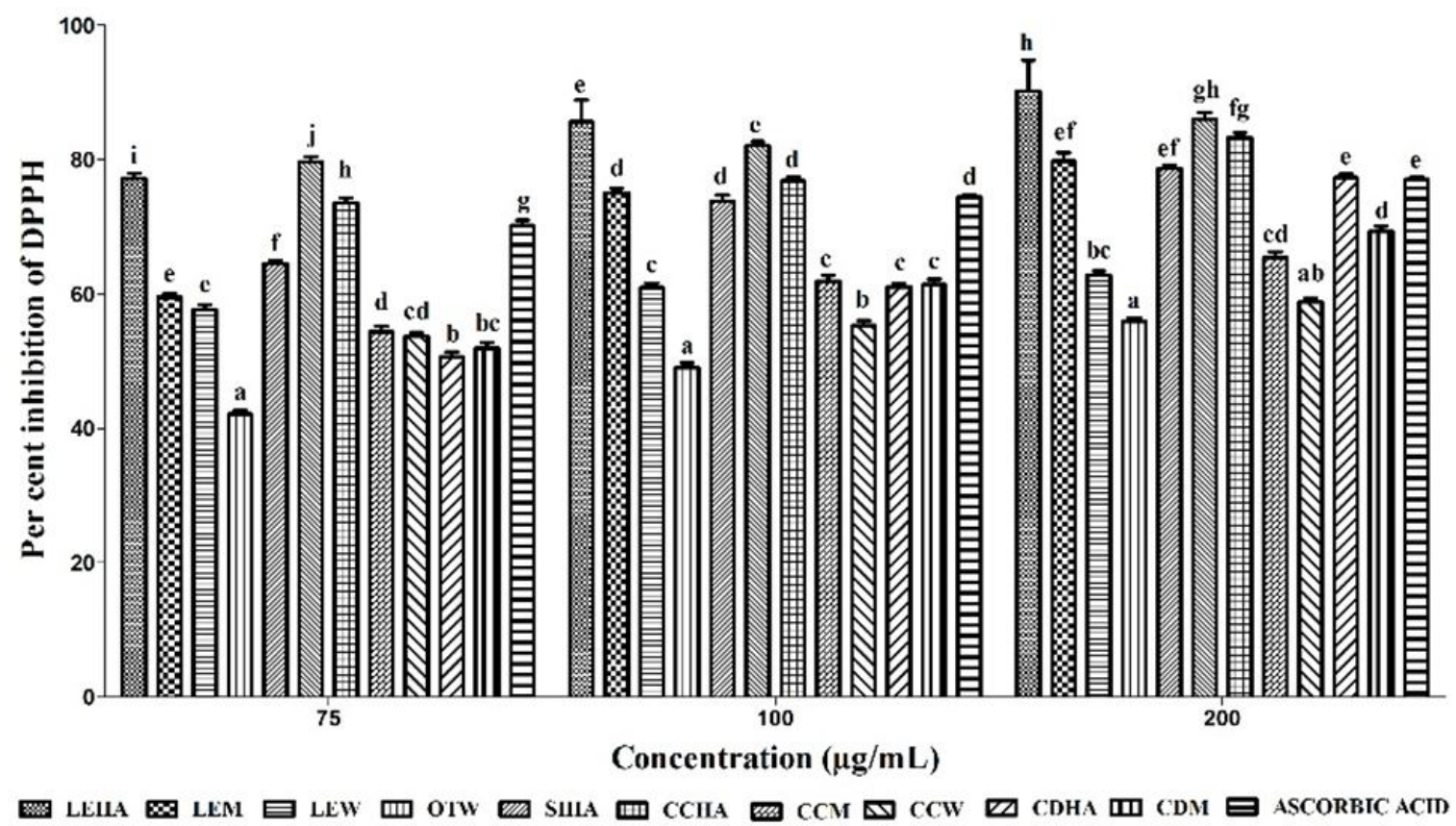

Figure 5: Per cent inhibition of DPPH by various extracts of plants and ascorbic acid. Values with different superscript were differ significantly at respective concentration $(p<0.05)$. 


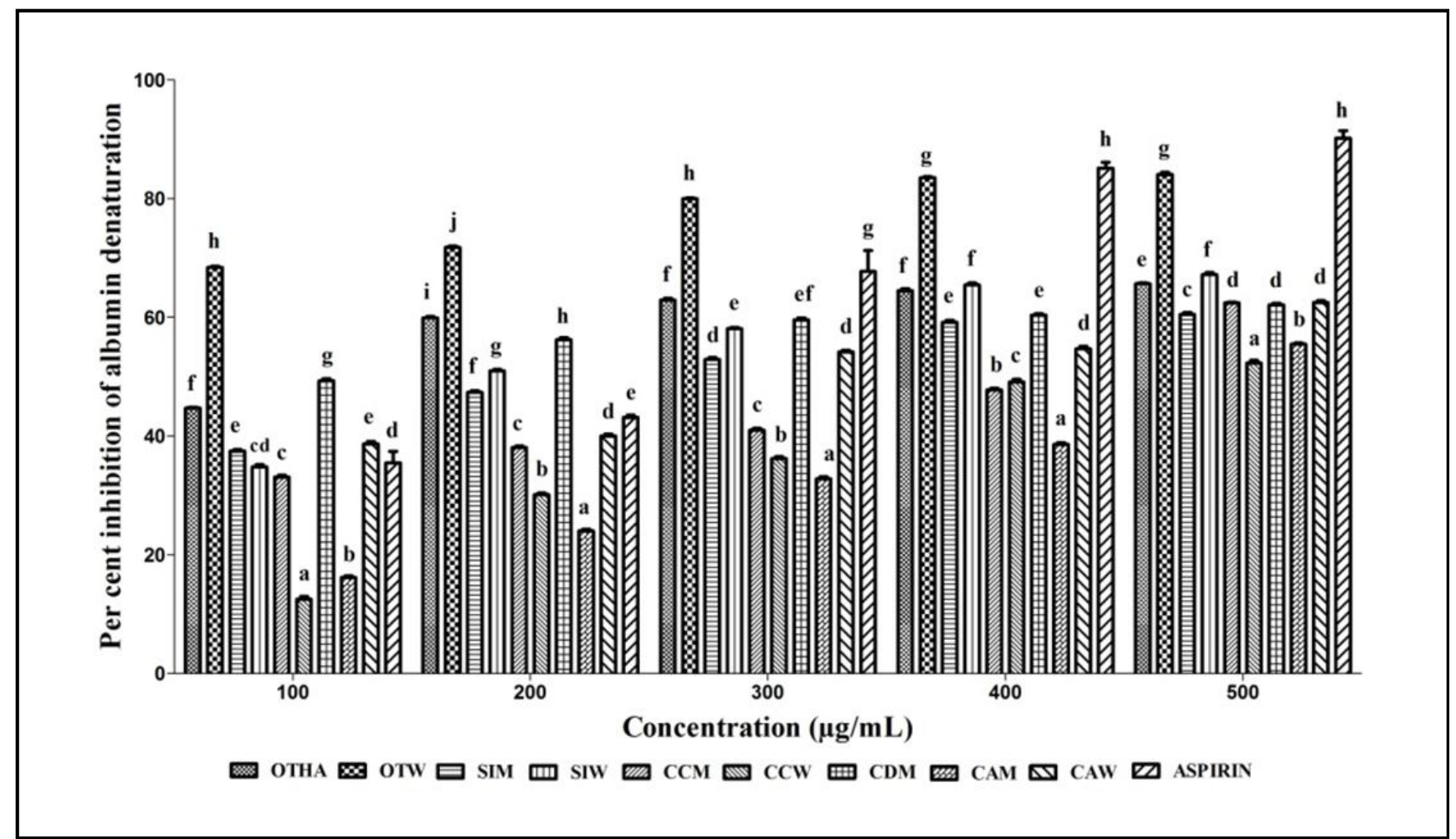

Figure 6: Per cent inhibition of albumin denaturation by various extracts of plants and aspirin. Values with different superscript were differ significantly at respective concentration $(p<0.05)$.

\section{Discussion}

In a phytochemical analysis of all extracts, flavonoids were found in all the extracts except hydro-alcoholic extract of $O$. turpethum. All the extracts of S. indicus and C. absus were found to have an alkaloid. Chaksine and isochaksine, two water-soluble alkaloids have been isolated from the seed of C. absus (Siddqui and Ahmed, 1935). Sterols were absent in water extract of all the plants. The reason might be the presence of cyclopentanoperhydrophenanthrene ring and less solubility of phytosterols in the solvent used in the test (Moreau and Hicks, 2004).

An alpha-amylase is one of the most widely studied targets in diabetic research. An alpha-amylase is responsible for the conversion of starch molecules into simple sugar molecules which absorb in the body and raises blood glucose level (Gopinath et al., 2017). Alpha-glucosidase is located in the intestinal cells, which hydrolyse carbohydrate and activates at the end of digestion. This enzyme converts complex sugar molecules into absorbable monosaccharide. Under the diabetic condition, this enzyme converts the sugar molecules and releases into blood stream, results in hyperglycaemia (da Costa et al., 2019). Various phytochemicals like flavonoids, alkaloids and saponin may have alpha-glucosidase inhibitory activity and may bind with enzyme non-competitively, and so, plant extract containing these kinds of phytochemicals may exhibit antidiabetic activity via inhibition of alpha-glucosidase (Telagari and Hullatti, 2015).

L. echinata is a climber plant with the presence of various phytochemicals in the fruits like cucurbitacin B, C, saponin, $\beta$-sitosterol, and flavonoids. In the present study, hydro-alcoholic extract of $L$. echinata has found to inhibit the alpha-glucosidase enzyme and also the DPPH, which indicated to have an antidiabetic and antioxidant potential. Chrysoeriol is a principle flavonoid found in the fruit and has been reported with antidiabetic effect (Khare, 2007; Dludla et al., 2017). Different pharmacological activities have been reported for fruits (Giri et al., 2014). The principal component of fruit is cucurbitacin, a diterpene, having strong antioxidant action (Kaushik et al., 2015). This finding may be supported by total phenolic content measured in the present experiment. All the extracts of $L$. echinata showed the higher amount of total phenolic content (Table 4). Hydro-alcoholic extract of L. echinata fruit has been reported to reduce blood glucose in alloxan-treated rats (Dogar et al., 2018). In the present study, we found that the plant also has a significant effect against $\mathrm{DPPH}$, which is similar to observation reported in a previous study (Sharma et al., 2012). It is postulated that antioxidant activity is mainly due to the phenolic content present in the plant. As an important phytochemical bearing very reactive hydroxyl group, phenolics have attributed antioxidant action (Bidchol et al., 2011; Bhatt et al., 2019a). In this study, in vitro antiinflammatory activity has not been seen with fruits of L. echinata.

C. absus is an erect annual plant used traditionally in various ailments. The seed contains unique quaternary water-soluble alkaloid, namely; chaksine and isochaksine, flavonoids like apigenin, quercetin, luteolin and hydnocarpin, glycoside like aloe-emodin and chrysophanol, phenolic compounds like coumaric acid, gentisic acid and syringic acid, triterpenes like beta-amyrin and cycloartenol. Various pharmacological activities have been reported for C. absus seeds. In vitro antidiabetic activity of $C$. absus seed is reported for only 
chloroform, methanol extract and various fractions against alphaamylase (Hussain et al., 2015) but not evaluated against alphaglucosidase. In the present study, hydro-alcoholic extract of C. absus showed significant inhibition of alpha-amylase and alpha-glucosidase enzymes and shown to have an antidiabetic effect. In the present study, the inhibition of DPPH by extracts of $C$. absus was not remarkable. However, it has been reported that Cassia species have the antioxidant property (Jayaraman et al., 2014).

O. turpethum is found to have various glycosides like turpethine, operculinosides, and various steroidal glycosides like stigmasterol (Gupta and Ved, 2017). O. turpethum root and stem are explored for its pharmacological actions (Gupta and Ved, 2017). No study has been reported on in vitro alpha-amylase and alpha-glucosidase inhibition by an extract from leaves. However, in vitro antiinflammatory activity of $O$. turpethum root has been reported (Sharma and Singh, 2013). In the present study, extracts of O. turpethum did not produce remarkable inhibition of alpha-amylase and alphaglucosidase. However, water extract of $O$. turpethum produced significant inhibition of albumin denaturation which may be due to aglycon moiety of the glycoside, which is in general considered as pharmacologically active (Wang et al., 2018).

S. indicus is widely used for the treatment of epilepsy, mental illness, jaundice, hepatopathy, diabetes, leprosy, cough, gastropathy, helminthiasis and skin diseases. The plant is rich in alkaloid like sphaeranthine, flavanoid C-glycoside and isoflavone glycoside (Galani et al., 2010). No reports on in vitro antidiabetic and anti-inflammatory activity of the plant have been observed. However, in vitro antioxidant activity of ethanol extract of $S$. indicus has been reported (Shirwaikar et al., 2006; Tiwari and Khosa, 2009). In the present study, the methanolic extract of the plant showed little inhibition of alphaglucosidase enzyme,but hydro-alcoholic and methanolic extracts showed remarkable effect in DPPH assay which indicates that the phytochemicals present in the plants have antioxidant potential. Water and methanolic extracts also showed inhibition of albumin denaturation, but the result was not significant.

C. cretica is a perennial plant found in the coastal areas of Gujarat which contains flavonoids like quercetin glucoside, rutin and various phenolic acids. Quercetin is known to have antidiabetic action (Kotadiya et al., 2017). In the present study, the water extract of the plant showed good inhibition of alpha-amylase and alpha-glucosidase as compared to other extracts. The methanol extract of whole herb C. cretica did not show the inhibition of alpha-glucosidase as per previous report (El-Manawaty and Gohar, 2018). The hydro-alcoholic and methanolic extract showed antioxidant effect in DPPH assay, but the effect was not comparable to ascorbic acid. Water and ethanol extract of $C$. cretica leaves have been reported to have a strong antioxidant effect against various free radicals like DPPH, ferric chloride, peroxides, etc. (Afshari and Sayyed-Alangi, 2017). No reports have been found on in vitro anti-inflammatory activity of the plant. In the present study, we observed less effect against albumin denaturation indicates that the plant does not have anti-inflammatory effect.

C. depressus is traditionally used in pain, fever, sexual dysfunction and to treat gonorrhoea. From the whole plant, sitosterol glucoside, sitosterol, apigenin and luteolin, three new $\alpha$-amyrin derivatives, cordepressic acid, cordepressenic acid and cordepressin have been isolated (Khan et al., 1991; Khare, 2007). In the present study, methanolic and water extract of the plant showed the remarkable antidiabetic effect with inhibition of alpha-amylase only. Hydroalcoholic and methanolic extracts of the plant also showed inhibition of alpha-glucosidase and DPPH. The dichloromethane and methanolic extracts of the $C$. depressus have also been reported to have antioxidant and antidiabetic effects (Samina et al., 2017). We also observed the effect of the methanolic extract on albumin denaturation, but the effect was lesser.

Table 4: Total phenolic content (mg GAE per gram) of different extracts of medicinal plants

\begin{tabular}{|c|c|c|c|c|}
\hline \multirow{3}{*}{ Sr. No. } & \multirow{3}{*}{ Name of plant } & \multicolumn{3}{|c|}{ Type of extract } \\
\hline & & HAE & ME & WE \\
\hline & & \multicolumn{3}{|c|}{ mg GAE per gram } \\
\hline 1 & Luffa echinata & $257.52 \pm 7.14$ & $363.01 \pm 14.01$ & $232.91 \pm 4.39$ \\
\hline 2 & Operculina turpenthum & $24.75 \pm 5.49$ & $19.83 \pm 9.67$ & $12.80 \pm 4.61$ \\
\hline 3 & Sphaeranthus indicus & $213.22 \pm 3.72$ & $100.00 \pm 5.58$ & $59.21 \pm 3.07$ \\
\hline 4 & Cressa cretica & $9.28 \pm 4.22$ & $50.07 \pm 7.44$ & $40.93 \pm 5.58$ \\
\hline 5 & Corchorus depressus & $42.33 \pm 8.11$ & $195.64 \pm 7.34$ & $268.78 \pm 4.39$ \\
\hline 6 & Cassia absus & $45.15 \pm 6.78$ & $57.81 \pm 3.22$ & $36.71 \pm 4.39$ \\
\hline
\end{tabular}

ALK: Alkaloid, GLY: Glycoside, SP: Saponin, FLV: Flavonoid, STR: Steroid, CHO= carbohydrate/sugars TN: Tannin, HAE: Hydro-alcoholic extract; ME: Methanol extract; WE: Water extract; '+'=present; '-'=absent

\section{Conclusion}

Hydro-alcoholic and methanolic extracts of $L$. echinata fruit, an aqueous extract of $C$. cretica leaf and methanolic and hydro-alcoholic extracts of $C$. depressus root have shown good in vitro antidiabetic activity. Hydro-alcoholic and methanolic extracts of L. echinata fruit and methanolic extract of $S$. indicus fruit showed significant in vitro antioxidant effect. Aqueous extract of $O$. turpethum leaf produced remarkable anti-inflammatory activity. Further, isolation and identification of active principles from these plant sources may be helpful to explore pharmacological activity.

\section{Conflict of interest}

The authors declare that there are no conflicts of interest in the course of conducting the research. All the authors had final decision regarding the manuscript and decision to submit the findings for publication. 


\section{References}

Afshari, A. and Sayyed-Alangi, S. (2017). Antioxidant effect of leaf extracts from Cressa cretica against oxidation process in soybean oil. Food Sci. Nutr., 5(2):324-333.

Afzal, S.; Chaudhry, B.A.; Ahmad, A.; Uzair, M. and Afzal, K. (2017). Antioxidant, acetylcholinesterase, butyrylcholinesterase, and $\alpha$-glucosidase inhibitory activities of Corchorus depressus. Pharmacogn. Mag., 13(52):647-651.

Alhakmani, F.; Khan, S.A. and Ahmad, A. (2014). Determination of total phenol, In vitro antioxidant and anti-inflammatory activity of seeds and fruits of Zizyphus spina-christi grown in Oman. Asian Pac. J. Trop. Biomed., 4(Suppl.2):S656-S660.

Bhatt, P.R.; Patel, U.D.; Modi, C.M.; Pandya, K.B. and Patel, H.B. (2019a). Thinlayer chromatography and in vitro free radical scavenging activity of few medicinal plants from the surroundings of Junagadh, Gujarat, India. Ann. Phytomed., 8(1):45-55.

Bhatt, P. R.; Pandya, K. B.; Patel, U. D.; Patel H. B. and Modi, C. M. (2019b). Survey on Ethnoveterinary Practices around Junagadh,Gujarat, India. Indian J. Pharm. Sci., 81(1):161-167.

Bidchol, A. M.; Wilfred, A.; Abhijna, P. and Harish, R. (2011). Free radical scavenging activity of Aqueous and Ethanolic extract of Brassica oleracea L. Var. Italica. Food Biopro. Technol., 4(7):1137-1143.

Brown, J. E. and Rice-Evans C. A. (1998). Luteolin-rich artichoke extract protects low-density lipoprotein from oxidation in vitro. Free Radic. Res., 29(3):247-255.

Da Costa, S. G.; Bates, P.; Dillon, R. and Genta, F. A. (2019). Characterization of $\alpha$-glucosidases from Lutzomyia longipalpis reveals independent hydrolysis systems for plant or blood Sugars. Front. Physiol., 10:1-15.

Dogar, R.; Yadav, S. K.; Nagori, B. P.; Mathur, K. and Goyal, M. (2018) Hypoglycaemic effect of Luffa echinata in alloxan induced diabetic rats. Indian J. Drugs, 6(4):201-217.

El-Manawaty, M. A. and Gohar, L. (2018). In vitro alpha-glucosidase inhibitory activity of Egyptian plant extracts as an indication for their antidiabetic activity. Asian J. Pharm. Clin. Res., 11(7):360-367.

Encarnacão, S.; de Mello-Sampayoa, C.; Graça, N.A. G.; Catarinob, L.; Moreira da Silvaa, I. B.; Limaa, B. S. and Duarte Silvaa, O. M. (2016). Total phenolic content, antioxidant activity and pre-clinical safety evaluation of an Anacardium occidentale stem bark Portuguese hypoglycaemic traditional herbal preparation. Ind. Crop. Prod., 82:171-178.

Iqbal, E.; Salim, K. A. and Lim, L. B. L. (2013). Phytochemical screening, total phenolics and antioxidant activities of bark and leaf extracts of Goniothalamus velutinus (Airy Shaw) from Brunei Darussalam. J. King Saud Univ. Sci., 27(3):224-232.

Fawole, O.A.; Amoo, S.O.; Ndhlala, A.R.; Light, M.E.; Finnie, J.F. and Van Staden, J. (2010). Anti-inflammatory, anticholinesterase, antioxidant and phytochemical properties of medicinal plants used for pain-related ailments in South Africa. J. Ethnopharmacol., 127(2):235-241.

Galani, V. J.; Patel, B. G. and Rana D. G. (2010). Sphaeranthus indicus Linn. A phytopharmacological Review. Int. J. Ayur. Res., 1(4):247-253.

Giri, S.; Lokesh, C. R.; Sahu, S. and Gupta, N. (2014). Luffa echinata: Healer plant or potential killer? J. Postgrad. Med., 60(1):72-74.

Gopinath B. S.; Anbu, P.; Md Arshad M. K.; Lakshmipriya, T.; Hong Voon, C.; Hashim, U. and Chinni, S. V. (2017). Biotechnological processes in microbial amylase production. Biomed. Res. Int., pp:1-9.

Gupta, S. and Ved, A. (2017). Operculina turpethum (Linn.) Silva Manso as a Medicinal Plant Species: A review on bioactive components and pharmacological properties. Pharmacogn. Rev., 11(22):158-166.

Harborne, A. J. (1998). Phytochemical methods-A guide to modern techniques of plant analysis. $3^{\text {rd }}$ edn. Springer science, Netherland.
Hussain, F.; Shahid, M. and Javed, K. (2015). Antioxidant, antiglycation and alpha amylase inhibitory activities of Cassia absus seeds. Curr. Sci. Perspect., 2(1):5-9.

Jayaraman, P.; Sivaprakasam, E.; Rajesh, V.; Mathivanan, K. and Arumugam, P. (2014). Comparative analysis of antioxidant activity and phytochemical potential of Cassia absus Linn.; Cassia auriculata Linn. and Cassia fistula Linn. Indian J. Drug Dis., 3(1):298-304.

Kaneria, M.; Baravalia, Y.; Vaghasiya, Y. and Chanda, S. (2009). Determination of antibacterial and antioxidant potential of some medicinal plants from Saurashtra region, India. Indian J. Pharm. Sci., 71(4):406-412.

Kaushik, U.; Aeri, V. and Mir, S. R. (2015). Cucurbitacins: An insight into medicinal leads from nature. Pharmacogn. Rev., 9(17):12-18.

Khan, M.Y.; Javed, K.; Khan, M. H.; shamsi, M. A. and Siddiqui, A. A. (1991). $\alpha$-amyrin derivatives from Corchorus depressus. Phytochem., 30(6):1989-1992.

Khare, C. P. (2007). Indian Medicinal Plants: An illustrated dictionary. $1^{\text {st }}$ Edn. Springer. New Delhi, India.

Kotadiya, C. R.; Patel, U. D.; Chauhan, V. B.; Patel, H. B.; Modi, C. M.; Bhatt, P. R.; Pandya, K. B. and Shah, T. M. (2017). In vitro antioxidant and antidiabetic activity of hydro-alcoholicextract of Opuntia elatior fruit as well as quercetin. Int. J. Sci. Environ. Tech., 6(2):1028-1035.

Modak, M.; Dixit, P.; Londhe, J.; Ghaskadbi, S. and Devasagayam, T. P. (2007). Indian herbs and herbal drugs used for the treatment of diabetes. J. Clin. Biochem. Nutr., 40(3):163-173.

Modi, C. M.; Bhatt, P. R.; Pandya, K. B.; Patel, H. B. and Patel, U. D. (2019) Comparative evaluation of in vitro anti-inflammatory activity of different extracts of selected medicinal plants from Saurashtra region, Gujarat, Int. J. Curr. Microbiol. Appl. Sci., 8(5):1686-1698.

Moreau, R. A. and Hicks, K. B. (2004). The in vitro hydrolysis of phytosterol conjugates in food matrices by mammalian digestive enzymes. Lipids, 39(8):769-776

Patel, H. B.; Patel, U. D.; Modi, C. M.; Bhatt, P. R. and Pandya, K. B. (2019). In vitro antidiabetic activity of various indigenous medicinal plants of Junagadh region (Gujarat, India). The Pharm. Innov. J., 8(4):1133-1138.

Patidar, A.; Birla, D.; Patel, V.R.; Chaturvedi, M. and Manocha, N. (2014). Areview on advantages of natural analgesics over conventional synthetic analgesics. Int. J. Pharm. Sci., 5(5):3534-3539.

Sarker, S.D.; Latif, Z and Gray, A. I. (2006). Natural product isolation. $2^{\text {nd }}$ Edn. Humana Press, New Jersey.

Scalbert, A.; Johnson, I. T. and Saltmarsh, M. (2005). Polyphenols: Antioxidants and beyond. American J. Clin. Nutr., 81(Suppl.1):215S-217S.

Senguttuvan, J.; Paulsamy, S. and Karthika, K. (2014). Phytochemical analysis and evaluation of leaf and root parts of the medicinal herb, Hypochaeris radicata $\mathrm{L}$. for in vitro antioxidant activities. Asian Pac. J. Trop. Biomed., 4(Suppl.1):S359-S367.

Sharma, V. and Singh, M. (2013). In vitro antiarthritic and hemolysis preventive: Membrane stabilizing efficacy of ethanolic root extract of Operculina turpethum. World J. Pharm. Pharm. Sci., 2(1):302-312.

Shirwaikar, A.; Prabhu, K. S. and Punitha S. R. (2006). In vitro antioxidant studies of spheranthus indicus (Linn). Indian J. Exp. Biol., 44: 993-996.

Siddiqui, S. and Ahmad, Z. (1935). Alkaloids from the seeds of Cassia absus, Linn. Proc. Indian Acad. Sci., 2(5):421-425.

Tellagari, M. and Hullati, K. (2015). In vitro $\alpha$-amylase and $\alpha$-glucosidase inhibitory activity of Adiantum caudatum Linn. and Celosia argentea Linn. extracts and fractions. Indian J. Pharmacol., 47(4): 425-429.

Tiwari, B. K. and Khosa, R. L. (2009). Hepatoprotective and antioxidant effect of Sphaeranthus indicus against acetaminophen-induced hepatotoxicity in rats. J. Pharm. Sci. Res., 1(2):26-30. 
Tortora, G. J. and Reynolds, S. (1993). Principles of anatomy and physiology. $7^{\text {th }}$ Edn. Harper Collins College Publishers, U.S.A., pp:695.

Wan, L.S.; Chen, C.P.; Xiao, Z.Q.; Wang, Y.L.; Min, Q.X.; Yue, Y. and Chen, J. (2013). In vitro and in vivo antidiabetic activity of Swertia kouitchensis extract. J. Ethnopharmacol., 147:622-630.

Wang, J.; Fang, X.; Ge, L.; Cao, F.; Zhao, L.; Wang, Z; and Xiao, W. (2018). Antitumor, antioxidant and anti-inflammatory activities of kaempferol and its corresponding glycosides and the enzymatic preparation of kaempferol. PloS One, 13(5):e0197563.

Williams, L. A. D.; O'Connar, A.; Latore, L.; Dennis, O.; Ringer, S.; Whittaker, J. A.; Conrad, J.; Vogler, B.; Rosner, H. and Kraus, W. (2008). The in vitro antidenaturation effects induced by natural products and non-steroidal compounds in heat treated (immunogenic) bovine serum albumin is proposed as a screening assay for the detection of anti-inflammatory compounds, without the use of animals, in the early stages of the drug discovery process. West Indian Med. J., 57(4):327-331.

World Health Organisation (WHO) global report on Diabetes (2018). Geneva: World Health Organization. Accessed from https://www.who.int/ diabetes/global-report/en/

World Health Organisation (WHO) global report on traditional and complementary medicine (2019). Geneva: World Health Organization. Accessed on $9^{\text {th }}$ September 2019. https://www.who.int/traditional-complementaryintegrative-medicine/en/

Zhipeng, Y.; Yin, Y.; Zhao, W.; Liu, J. and Chen, F. (2012). Antidiabetic activity peptides from albumin against $\alpha$-glucosidase and $\alpha$-amylase. Food Chem., 135(3):2078-2085.

Citation: Punit R. Bhatt, Kajal B. Pandya, Urvesh D. Patel, Chirag M. Modi, Harshad B. Patel and Bhavesh B. Javia (2019). Antidiabetic, antioxidant and anti-inflammatory activity of medicinal plants collected from nearby area of Junagadh, Gujarat. Ann. Phytomed., 8(2):75-84. 